\title{
The Impact efficiency of using assets to enhance earnings quality in the Jordanian Industrial Companies listed in the Amman Stock Exchange: An Empirical Study
}

\author{
Dr.Mohammed Abdullah Al-Momani ${ }^{1}$, Tareq Mohammad Almomani ${ }^{2}$ \\ ${ }^{1}$ Associate Professor, Accounting Department Jadara University-Jordan \\ ${ }^{2} \mathrm{Ph} . \mathrm{D}$. Student, Accounting at University Saince Islam Malaysia (USIM)
}

\begin{abstract}
The objective of this study is to investigate the impact of the efficiency of the use of assets to enhance earnings quality in Jordanian industrial companies listed in Amman Stock Exchange (ASE).To achieve the objectives of the study, a sample of 48 industrial companies was tested during the period of 2009-2015, and the number of observations used in the test was 336. To test the hypotheses of the study, multiple regression was used for the Pooled Data Regression. The study found that industrial companies achieved earnings quality. The study also found the existence of a positive impact that is statistically significant, of the efficiency of the use of assets (asset growth rate, working capital turnover, and the rate of current assets turnover), to enhance earnings quality. Accordingly, the study recommends that the management of companies maintains the earnings quality and exert more effort to exploit the company's assets with the best possible efficiency to achieve sales volume so that it can achieve earnings quality to enable it to continue its activities.
\end{abstract}

Keywords: Persisting Earnings, Asset Efficiency, Industrial Companies, And Earnings Quality.

\section{INTRODUCTION}

Financial statements reflect the Company's performance, and through its statement of financial position and earnings, users of financial statements can predict company's ability to continue and generate future earnings. Many researchers have expressed the persistence of the flow of current earnings in future periods with Earnings quality [12]. Earnings derived its importance by being used as the most important inputs in the financial and investment decision-making processes, and decisions vary depending on the different users of financial statements. For instance, shareholders perceive earnings as a measure of judgment on the performance of the company at the present and future time. Meanwhile, lenders rely on credit decisions and they are concerned about the borrowers' ability to repay loans and interest, and therefore, they focus on profits and continuance in the future, whereas investors use financial statements to evaluate their investments and predict future earnings [3]. FASB 1978, SFAC No.1 paragraph 47 states that: "Investors, creditors, and others use earnings information to help them (a) evaluate management's performance, (b) estimate "earning power" or other amounts they perceive as "representative" of long-term earning ability of an enterprise, (c) predict future earnings, or (d) assess the risk of investing in or lending to an enterprise." Therefore, earnings quality is the ability of earnings to meet the primary objective of financial reporting, providing relevant and reliable information to users such as investor, employees, lenders, suppliers and trade creditors, customers, and governments [4].

The most important decisions taken by corporate management are the financing and investment decisions. Financing decisions are related to obtaining the funds in the appropriate manner, in accordance with their circumstances. Meanwhile, investment decisions are related to directing the money and using it in current and fixed assets to achieve future returns associated with investment [5].

Fixed assets are that part of the assets that the company intends to obtain on a certain period (usually more than a year) and which are not consumed at their first use. Fixed assets are structured and they include: intangible assets, tangible assets, and financial assets. On the other hand, short-term assets represent the patrimonial elements which fulfill one of the following

Corresponding Author: Dr.Mohammed Abdullah Al-Momani, Associate Professor, Accounting Department Jadara University-Jordan, 01139391618 
characteristics: are bought or produced for own consumption or with the purpose of sale; are expected to be realized in not more than a year from the date of the balance sheet; are receivables afferent to the operational cycle; are found as cash or other equivalent of cash [6].

The company's survival and sustainability depend on the results of those decisions taken by the management. Therefore, corporate management seeks to achieve its strategic objective of maximizing the value of the company, which represents the economic justification for its continued economic activity [7]. Corporate managements seek to make their investment decisions achieve an increase in the expected return and increase in the value of the company.

Earnings management is among the important issues nowadays in the minds of investors, next to the issues of financial scandals and crises. The issue of earnings management occurred by the starting of the current century, where users' trust in financial reports declined, if not missed. Achieving persistence of earnings is considered to be one of the indicators of the success of the company's management. Accordingly, earnings quality is defined as earnings persistence, which means "the degree to which earnings performance persists into the next period." Benish and Vargus stated that "the quality of current earnings is the likelihood that the current earnings are sustainable in the future [8].

Managerial decisions are likely to contain information about earnings quality because managers make many decisions based on current and future profitability, and they arguably have the most precise and complete information about their firms' earnings quality and future profitability than other stakeholders. Therefore, to the extent that information asymmetry exists between managers and outsiders, earnings quality inferred from managerial decisions may provide incremental information to the existing empirical measures that are based on the information set of outside investors or the properties of the accounting numbers. Earnings quality gives a positive indication of the investment decisions, which is reflected by the efficiency of use of the company's fixed and current assets .

Corporate management may face a series of challenges, which necessitates that its investment decisions are carefully studied because the survival and sustainability of the company depend on the results of those decisions taken by it. Therefore, corporate management seeks to maximize the value of the company, through the achievement of earnings and persistence of earnings, which is the outcome of the results of efficiency of management in the use of the assets of the company. Therefore, the present study attempts to investigate the impact of the efficiency of usage assets (measured by asset turnover rate, asset growth rate, working capital turnover rate, and current asset turnover rate) on the earnings quality of Jordanian industrial companies listed on Amman Stock Exchange (ASE) for the period from 2009 to 2015 . The problem of the study can be formulated in answering the following question:

Is there an impact of the efficiency of using assets of the company (as measured by asset turnover rate, growth rate of assets, turnover of working capital and turnover of current assets) to enhance earnings quality in the industrial companies listed on ASE?

The importance of the study is that it discusses the efficiency of management in using the assets of the company. Also, the persisting earnings are important to investors, creditors, lenders, suppliers and other analysts, to help them to rationalize their economic decisions. Furthermore, profit information should accurately reflect the economic events that have taken place in the company, so as to reflect the stated operational performance of the company's profits, and give an indication of the operational performance of the future.

\section{LITERATURE REVIEWS}

Most of the previous literature agrees that accounting earnings reported in financial reports are considered as the most important information for users of financial statements and serve as a summary of the company's business and its achievements during the financial period [9]. Earnings quality is realized when earnings reflect the company's operating performance and when it gives an indication of the company's future operating performance [10]. In addition, some researchers used the persistence of earnings as an indicator of their quality [11], and they pointed out that continuity indicates the extent to which current earnings are related to the future. We note that earnings persistence indicates how much of current earnings will persist into the future and continue from period to period. Since earnings are divided into cash flows and accruals, the quality of earnings means that cash flows are more than accruals. The quality of earnings reflects the ability of earnings to express that the real 
earnings of the company are honest, and help financial analysts in the analysis of the current and future operating performance and value of the company. Therefore, the character of persistence of earnings is an attribute of quality [12].

Corporate governance is a system by which corporations are directed and managed. It specifies the relationship and distribution of rights and responsibilities among the providers of capital, the board, managers and other stakeholders (employees, consumer, the community and the state) of the corporation. The efficiency of management in using the assets of the company is accompanied by growth in sales and reflected on its performance. Here, growth in sales may be the result of growth in real investment in the company while high accruals reflect the state of growth in the company's activities. However, if there is an increase in accruals without being accompanied by growth in sales, then it is a sign of a decrease in efficiency in capital use or distortions in the accounting measurement, and the persistence of low earnings in companies with high accruals suggests problems in accounting measurement [13].

Earnings persistence is the extent to which current accounting earnings are related to future earnings [14]. Many studies have used earnings persistence as an indicator of their quality; they link current and future earnings, such as [12]. In this regard, if the persistence of cash flows is more than the persistence of accruals, it reflects the quality of earnings [2] [15]. Richardson et al. developed a model for measuring future earnings persistence by dividing earnings into their core components, which include cash flows and accruals [16]. The earnings quality indicators were divided into three main categories: earnings properties, investor responsiveness to earnings, and external indicators of earnings misstatements. However, the study could not reach a clear conclusion on the parameters of earnings quality because quality depends on the context in which it is judged. Earnings quality is also a function of the company's core performance indicators [17].

The results of several studies demonstrate that a relationship exists between the quality of earnings and management, and there are many things in common between the quality of earnings and management [18]. Also, Teets [19] describes quality of profits by the extent to which it reflected the economic performance of companies. In addition, Azoz et al. [20] found a significant positive relationship between board sizes and earning management.
-Darjezi, et al. [21] Suggested that working capital accruals, such as changes in accounts receivables and inventory, appear to contain important information about the earnings quality of firms and can help predict future return.

-Cristina Gaio and Lisboa Clara C. Raposo [22] showed a negative and statistically significant relation between corporate governance ratings and earnings quality rankings, suggesting that corporate governance and earnings quality are substitute mechanisms.

-Anjum et al. [23] Tested the impact of earnings management on the profitability of non-financial companies listed on Karachi Stock Exchange in Pakistan. The results show that earnings management has a negative impact on corporate profitability, as it reduces its credibility.

- A study by Hamdan [24] examined the factors that affect the quality of earnings of Jordanian industrial companies. The sample included 50 companies for the period of 2004-2009. The results of the study showed the high quality of the earnings of Jordanian companies. The outcomes also show an impact of the size of the company, debt contracts and the quality of audit on the quality of earnings.

-Naz et al. [25] tested the impact of the size of the company and the structure of capital on the management of earnings for the period of 2006-2010 for a sample of 75 companies from the industry of cement, sugar and chemicals in Pakistan. The results showed a negative impact between capital structure and earnings management, but there was no impact on the size of the company.

- Abu Ali, et al. [14] tested the effect of the quality of accounting earnings on the cost of equity. The study concluded that there is an impact of the quality of the accounting earnings in general on the cost of equity and the impact of accounting earnings characteristics separately on the cost of equity

\section{METHODOLOGY}

The main objective of the present study is investigate the impact of the efficiency of the use of assets to enhance earnings quality in Jordanian industrial companies listed in Amman Stock Exchange(ASE). The study population comprises all industrial public shareholding companies listed on Amman Stock Exchange, which accounted to 68 companies at the end of year 2015. A number of conditions have been set for selecting the sample of the study: if all the data requiring calculating the variables were available, they were not merged or 
stopped from trading during the study period (20092015). The number of Jordanian industrial companies that met the requirements was 48 . The data for the research purposes were extracted mainly from corporate annual reports.

\section{Research Hypotheses}

$\mathbf{H}_{\mathbf{0}}$ : There is no statistically significant impact of an efficiency of using the assets of the company (measured by Asset turnover rate, growth rate of assets, turnover of working capital and turnover of current assets) to enhance earnings quality in Jordanian industrial companies listed on ASE?

\section{Measurement of variables and the study model}

\section{First: The dependent variable:}

The persistence of the accounting earnings variable, has been calculated based on the use of a form [16], through the division of earnings to the basic components which include cash flow, and accruals, according to the following equation:

$$
\begin{aligned}
& \operatorname{ROA}_{i, t+1}=\gamma_{0, i}+\gamma_{1}\left(\operatorname{ROA}_{i, t}+\mathrm{TACC}_{i, t}\right)+ \\
& \gamma_{2}\left(\mathrm{TACC} C_{i, t}\right)+\varepsilon_{i, t} \ldots(1)
\end{aligned}
$$

Where:

$R O A_{i, t+1}$ : Rate of return on assets of the company (i) in the next year $(\mathrm{t}+1)$.

$R O A_{i, t}$ : Rate of return on assets of the company (i) in the current year $(\mathrm{t})$ (which is net profit divided by total assets).

$\gamma_{1}$ : Persistence of cash flows.

$\gamma_{2}$ : Persistence of accruals.

TACC $_{i, t}$ : The total entitlements of the company (i) in the current year $(\mathrm{t})$ are measured by the following equation: $\mathrm{TACC}_{\mathrm{i}, \mathrm{t}}=\mathrm{NI}_{\mathrm{i}, \mathrm{t}}-\mathrm{CFO}_{\mathrm{i}, \mathrm{t}}$

$\mathrm{NI}_{\mathrm{i}, \mathrm{t}}$ : Net operating income of the company (i) in the current year(t).

$\mathrm{CFO}_{\mathrm{i}, \mathrm{t}}$ : Net operating inflows of the Company (i) in the current year $(\mathrm{t})$.

According to Richardson's formula, earnings persisting was expressed next year from the rate of return on assets next year, $R O A_{i, t+1}$, This return is affected by earnings this year $R O A_{i, t}$, And the values of the coefficients $\gamma_{1}, \gamma_{2}$ and, if assumed in the previous equation that $\left(\gamma_{2}-\gamma_{1}\right)<0$, in order to focus on the relative persistence of accruals, that estimate modified version of (1)in which cash flow component of earnings is replaced by earnings performance, The equation can be expressed as follows:

$$
\begin{aligned}
& \operatorname{ROA}_{i, t+1}=\rho_{0, i}+\rho_{1}\left(\operatorname{ROA}_{i, t}\right)+\rho_{2}\left(\operatorname{TACC}_{i, t}\right)+ \\
& \varepsilon_{i, t+1} \ldots(2)
\end{aligned}
$$

The equation (2) can be rewritten in term of persistence parameters in equation (1) as:

$$
\begin{aligned}
& \operatorname{ROA}_{i, t+1}=\gamma_{0, i}+\gamma_{1}\left(\operatorname{ROA}_{i, t}\right)+\left(\gamma_{1}-\right. \\
& \left.\left.\gamma_{2}\right) T A C C_{i, t}\right)+\varepsilon_{i, t+1} \ldots(2)
\end{aligned}
$$

So $\left(\boldsymbol{\rho}_{\mathbf{1}}=\boldsymbol{\gamma}_{\mathbf{1}}\right)$ and $\boldsymbol{\rho}_{\mathbf{2}}=\left(\boldsymbol{\gamma}_{\mathbf{2}-} \boldsymbol{\gamma}_{\mathbf{1}}\right)$.This estimation provides a direct estimate of a value in equation (1) When the parameter value $\boldsymbol{\rho}_{\mathbf{2}}$ is less than zero any negative value there will be persistence in the earnings, ie the persistence of cash flows greater than the persistence of accruals in earnings, and earnings so that high persistence is considered high-quality.

\begin{tabular}{|c|c|c|}
\hline $\begin{array}{c}\text { Type of } \\
\text { variable }\end{array}$ & $\begin{array}{c}\text { Variables\& } \\
\text { Symbol }\end{array}$ & Method of calculation \\
\hline \multirow{2}{*}{ Independent } & Asset Growth & Total Asset $_{i . t+1}-$ Total Ass \\
\hline & $\operatorname{Rate}\left(G R W R_{\mathrm{it}}\right)$ & Total Asset ${ }_{i . t}$ \\
\hline \multirow{2}{*}{ Independent } & Asset turnover & net sales $_{i . t}$ \\
\hline & $\operatorname{rate}\left(A T R_{\mathrm{it}}\right)$ & $\overline{\text { Average Total Asset }}$ i.t \\
\hline \multirow{2}{*}{ Independent } & Working capital & net sales ${ }_{i . t}$ \\
\hline & rate $\left(W C R_{\mathrm{it}}\right)$ & $\overline{\text { Average Working capital }}{ }_{\text {i.t }}$ \\
\hline \multirow{2}{*}{ Independent } & Current Assets & net sales ${ }_{i . t}$ \\
\hline & Turnover $\left(C A R_{\mathrm{it}}\right)$ & Average Total current Ass \\
\hline Dependent & $\begin{array}{l}\text { Earnings } \\
\text { quality }\left(P E_{i, t+1}\right)\end{array}$ & $\begin{array}{l}\text { Using Richardson model } \\
\text { (Richardson et al, 2005) }\end{array}$ \\
\hline
\end{tabular}

\section{Study model}

The model can be formulated as follows:

$$
\begin{aligned}
P E_{i, t+1}=\beta_{0}+\beta_{1} \mathrm{GRWR}_{i, t}+\beta_{2} \mathrm{ATR}_{i, t} \\
+\beta_{3} \mathrm{WGR}_{i, t}+\beta_{4} \mathrm{CAR}_{i, t} \\
+\varepsilon_{i, t} \ldots \ldots \ldots \ldots \ldots \ldots \ldots(1)
\end{aligned}
$$

Table (1): indicates the methods andsymbol of measuring variables.

\section{RESULTS AND DISCUSSION}

To examine whether data is appropriate for analysis and measurement and to ultimately achieve the objectives of the study, several tests had been carried out, such as normal distribution test, and multicollinearity test. Also, since VIF for all variables is not more than 5, no overlapping is available among variables [26]. 


\section{Descriptive statistics of the variables of the study}

The results shown in Table (2) demonstrate that the ( 【GRWR】_it) of the companies of the study sample reached $5 \%$ with a standard deviation 0.18 . The results indicate that the highest growth rate was $114 \%$ and the lowest growth rate was $-66 \%$, while the value of intermediate growth rate was $-0.4 \%$, which is a negative ratio. This means that there is a difference in growth rates between companies. The researcher believes that growth is a desirable goal because it is an indication of the success of the company's performance and the expansion of its business and increase earnings.

The results shown in Table (2) demonstrate that ( $\$ ATR $\left.\rrbracket \_i t\right)$ in companies reached 0.62 times. This means that the average total assets of the study sample companies generate $\$ 0.62$ net sales per dollar invested in total assets. This shows that companies have not generated enough sales which commensurate with the volume of investment in their assets, and net annual sales do not reach their average assets. The results show that the average value of the assets was 0.58 and recorded the maximum turnover of assets of 2.20 once, zero time, and a minimum standard deviation of 0.395 .

The results shown in Table (2) demonstrate that ( 『WCR】_it) of the sample companies was 1.53 times. This means that the average working capital turnover of the study sample companies can generate $\$ 1.53$ net sales for each dollar invested in it. The maximum value was 21.40 times, and the minimum was -19.4. Also, the results show that some corporate departments did not have the operational capacity of working capital to generate sufficient sales that commensurate with the size of investment in it, or that their current liabilities exceed their current assets.

The results showed in Table (2) demonstrate that ( \CAR \_it) of the study's sample companies study reached 1.35 times. This means that the average current assets for sample companies generate $\$ 1.35$ net sales per dollar invested in their current assets. The results show that the intermediate value was 1.06 times, with the maximum turnover of 10.4 times, zero times in minimum, and a standard deviation of 0.95 .

Table (2): Statistical Description of Variables

\begin{tabular}{|l|l|l|l|l|}
\hline & $\boldsymbol{G R W}_{\text {it }}$ & $\boldsymbol{A T R}_{\text {it }}$ & $\boldsymbol{W C R}_{\text {it }}$ & $\boldsymbol{C A R}_{\text {it }}$ \\
\hline Mean & 0.005 & 0.62 & 1.531 & 1.35 \\
\hline Median & -0.004 & 0.58 & 1.56 & 1.06 \\
\hline Max. & 1.14 & 2.20 & 21.40 & 10.4 \\
\hline Min. & -0.66 & 0.000 & -19.4 & 0.000 \\
\hline St.Dev. & 0.18 & 0.395 & 1.61 & 0.95 \\
\hline Observation & 336 & 336 & 336 & 336 \\
\hline
\end{tabular}

\section{Hypotheses Testing}

The hypothesis tests the efficiency of the use of the company's assets for persistence of the earnings in the industrial companies. The multiple regression test for Pooled Data Regression was used to test the hypothesis. Table (3) shows that the calculated value of $(F)$ is 6.728 with a significant value of (p-value = 0.0003 ) at a significant level of $5 \%$. These results reject the null hypothesis and accept the alternative hypothesis, indicating a statistically significant impact on the efficiency of using the company's assets (as measured by asset turnover rate, growth rate of assets, turnover of working capital and turnover of current assets) to enhance earnings quality .

The results also showed that the value of Adjusted $\mathrm{R}^{\wedge} 2$ equals $35.8 \%$, which means that the change of $1 \%$ in the capital structure accounts for $35.8 \%$ of the change in the persistence of earnings, and this indicates that there is at least one impact of one of the indicators of asset-use efficiency whose contribution is clear in explaining the variance in the persistence of earnings ( \PE】_(i,t+1)). According to the results in Table (3), ( \GRWR \_it,) ( 『ATR $\rrbracket \_$it) and ( \WCR】_it) had a positive impact of statistical significance at a significant level of 5\% in the persistence of earnings ( \PE】_ $(i, t+1))$. Meanwhile, the results showed that the turnover of current assets ( \CAR】_it) has a positive impact of statistical significance at a significant level of $10 \%$. The researcher believes that the management of industrial companies for the study sample generally used assets (fixed and current) positive efficiently in light of the difficult economic challenges they face to achieve persistence in their earnings. The result agreed with the study of Abdul Jalil (2014) with respect to the rate of asset turnover, and growth rate.

Table (3): Results hypothesis test

\begin{tabular}{|c|c|c|c|}
\hline \multirow[t]{2}{*}{ Model $_{1}$} & \multicolumn{3}{|c|}{$\begin{aligned} P E_{i, t+1}=\beta_{0}+\beta_{4} & \mathrm{GWW}_{i, t} \\
& +\beta_{5} \mathrm{ATR}_{i, t} \\
& +\beta_{6} \mathbf{W G R}_{i, t} \\
& +\beta_{7} \mathrm{CAR}_{i, t} \\
& +\varepsilon_{i, t}\end{aligned}$} \\
\hline & $\beta$ & $\mathbf{T}$ & Sig. \\
\hline constant & -0.039 & -3.386 & 0.001 \\
\hline$G R W R_{\mathrm{it}}$ & 0.176 & 3.23 & $0.002^{*}$ \\
\hline$A T R_{\mathrm{it}}$ & 0.036 & 2.03 & $0.049^{*}$ \\
\hline$W C R_{\mathrm{it}}$ & 0.018 & 2.70 & $0.01^{*}$ \\
\hline$C A R_{\text {it }}$ & 0.013 & 1.92 & $0.062^{* *}$ \\
\hline $\mathbf{R}^{2}$ & \multicolumn{3}{|c|}{0.421} \\
\hline Adjusted R ${ }^{2}$ & \multicolumn{3}{|c|}{0.358} \\
\hline F-Test & \multicolumn{3}{|c|}{6.728} \\
\hline p-value & \multicolumn{3}{|c|}{$0.0003^{*}$} \\
\hline
\end{tabular}




\begin{tabular}{|c|c|}
\hline $\begin{array}{c}\text { Durbin - } \\
\text { Watson }\end{array}$ & 1.669 \\
\hline
\end{tabular}

*Sig. at $\alpha \leq 5 \%$.

$* *$ Sig. at $\alpha \leq 10 \%$.

\section{CONCLUSIONS}

The main objective of the study is to investigate the impact of the efficiency of using assets to enhance earnings quality in Jordanian industrial companies listed in Amman Stock Exchange (ASE) along the period from 2009 to 2015 . Based on the data analysis and hypotheses testing, the study finds that ASE achieved the persistence of their earnings in the period from 2009 to 2015 . The study also finds a positive impact of statistically significant indicators of the efficiency of the use of assets represented by the assets growth rate, working capital turnover, current assets turnover, and assets turnover rate, to enhance earnings quality .

One conclusion this study reaches is that there is a wide disparity between the industrial companies listed on ASE in achieving assets growth rate and asset turnover rate, many of which have a decline in rates. Moreover, there is a modest efficiency of the management of industrial companies in the use of the assets of the company, which was expressed in the assets turnover rate, working capital turnover, and current assets turnover rate. The recommendations for future research include examining other economic sectors such as the services and financial sector, using other models to measure the persistence of earnings, and including new variables in addition to what have been studied in order to expand the characteristics of the governing body in companies.

\section{REFERENCES}

[1] Richardson Scott, (2003)"Earnings Quality and Short Sellers", Accounting Horizons, Supplement, pp 49-61.

[2] Sloan, R.; (1996). "Do Stock Prices Fully Reflect Information in Accrual and Cash Flows About Future Earnings"; The Accounting Review; Vol. 7; No. 3; pp. 289-315.

[3] Bellovery, JodiL. Don E. Giacom., \&Michael D.Akers., (2005) .Earnings Quality: Its Time to Measure and Report. The CPA Journal, pp: 3237.

[4] Entwistle, G.M., Phillips, F., 2003. Relevance, reliability, and the earnings quality debate. Issues in Accounting Education 18 (1), 79-92.
[5] Almiri, Mohamed Ali (2013), Modern Financial Management, First Edition, Dar Wael Publishing and Distribution, Amman-Jordan.

[6] C. Caruntu, L. M. Lapadusi (2014): Reflection of the Economic Rate of Return in the Fixed Rate of Return in the Efficiency Use of the Fixed and Current Assets with Case Study in Mettalurgy. Metalurgija 53 (2014) 4, 668-672

[7] Al-Zubaidi, Hamza Mahmoud (2008), Advanced Financial Management, Second Edition, Al-Warraq Publishing \& Distribution, Amman- Jordan.

[8] Beneish, M., Vargus, M., 2002. Insider training, earnings quality, and accrual mispricing. The Accounting Review 77, 755-791.

[9] Barth, M, Cram, D. and Nelson, K., (2001), Accruals and the prediction of future cash flow. The Accounting Review, 76, 27-58.

[10] Dechow P., and Schrand, C., (2004).Earnings Quality.The Research Foundation of CFA Institute

[11] Altamuro, J, and Beaty, A.(2006).Do Internal Control Reform Improve Earnings Quality? Working Paper.www.ssrn.com.

[12] Schipper, K. And Vincent, L, (2003). Earnings quality, Accounting Horizons, Vol. 17, supplement, P. 97- 110.

[13] Richardson, S., Sloan, R., Soliman, M., and Tuna, I., (2006). The implications of accounting distortions and growth for accruals and profitability. The Accounting Review; 81,713743.

[14] Abu Ali, Suzy, Al-Dubai, Mamoun, and Abu Nasar, Mohamed (2011), The Effect of earnings quality on the cost of Equity Using international financial reporting standards. Jordanian Journal of Business Administration, Volume 7, Issue 1, pp. 67-94.

[15] Francis, J. LaFond, R. and Schipper, K. (2004), the market pricing of earnings quality.www. sssn.com.

[16] Richardson, S., Sloan, R., Soliman, M., and Tuna, I., (2005). Accrual Reliability Earnings Persistence and Stock Prices, Journal of Accounting and .Economics, Vol. 39(2), P. 473485.

[17]Dechow, P., Ge., W., and Schrand, C., (2010). Understanding Earnings Quality: A Review of the Proxies, Their Determinants and their Consequences. Journal of Accounting and Economics, Vol. 50 (2010), P. 344-401.

[18]Lo, Kin. 2007, "Earnings Management and Earnings Quality," Sauder School of Business, 
The University of British Columbia, Working Paper Series, www.SSRN Electronic Library.

[19] Teets, Walter R., 2002, " Quality of Earnings: An Introduction to the Issues in Accounting Education Special Issue," Issues in Accounting Education. Vol. 17, No. 4.

[20] Azzoz, A.R.A.M., and Khamees, B.A., (2015), "The Impact of Corporate Governance Characteristics on Earnings Quality and Earnings Management: Evidence from Jordan." Jordan Journal of Business Administration, Volume 12, No. 1, 2016.

[21]Darjezi,J .I ,Khansalar ,E. and Holt, A. (2015).The Role Capital Accruals on Quality and Stock Return,International Journal of Economics and Finnance.Vol.7.No.9.

[22] Cristina Gaio and Lisboa Clara C. Raposo (2014). Corporate Governance and Earnings Quality: International Evidence. Journal of Accounting and Finance vol. 14(3) 2014.
[23] Anjum, N., Saif, I., Malik, Q., and Hassan, S., (2012). Earnings Management and Firms' Profitability: Evidence from Pakistan. European Journal of Economics, Finance and Administrative Sciences, ISSN 1450-2275 Issue 47.

[24] Hamdan, Allam Mohamed (2012), Factors Influencing the Level of Earnings Quality: evidence from the Jordanian industrial corporations. Journal of the Islamic University for Economic and Administrative Studies, Volume 20, Issue 1, pp. 285-301.

[25] Naz,I. Bhatti, K., Ghafoor, A. and Hussain ,Kahan, H.(2011), Impact of firm Size and Capital Structure on Earnings of Management : Evidence from Pakistan. International Journal of Contemporary Business Studies, 12(2), pp: 22-31.

[26] Gujarati, D. (2003).Basic Econometrics. Fourth Edition, McGraw- Hill. 